\title{
IZDVOJENO MIŠLJENJE U PRAKSI USTAVNOG SUDA CRNE GORE
}

\author{
UDK: $347.991(497.16)$ \\ $347.92(497.16)$ \\ DOI: $10.31141 /$ zrpfs.2021.58.141.683 \\ Izvorni znanstveni rad \\ Primljeno: 20. siječnja 2021.
}

\begin{abstract}
Predmet rada je pravni institut izdvojenog/odvojenog mišljenja sudije, odnosno sudija koji se ne slažu s odlukom za koju je glasala većina sudija ustavnog suda, bilo u njenoj izreci ili u dijelu izreke bilo u obrazloženju ili dijelu obrazloženja. Izdvojeno mišljenje obrađuje se s istorijskog, komparativnog i pravno-teorijskog aspekta. Ukazano je na razloge koji idu u prilog i protiv izdvojenog mišljenja, sudijsku nezavisnost i njihov uticaj na integritet suda, kao i prijedloge za poboljšavanje pravnog okvira izdvojenog mišljenja i njihov uticaj na kreiranje pravnog sistema. U praksi Ustavnog suda Crne Gore izdvojena mišljenja su dozvoljena, ali ne i njihovo objavljivanje, jer je na odluci Ustavnog suda da li će se ono objaviti u "Službenom listu Crne Gore" ili ne. Praksa Ustavnog suda pokazuje uzdržanost sudija Ustavnog suda u korišćenju mogućnosti da izdvoje mišljenje a i nedefinisanosti ovog instituta na pravi način.
\end{abstract}

Ključne riječi: ustavno sudstvo, Ustavni sud Crne Gore, izdvojeno mišljenje, značaj

\section{POJAM I VRSTE IZDVOJENOG MIŠLJENJA}

\subsection{Pojam izdvojenog mišljenja}

Izvjesnost rješenja spora u sudskom postupku, što nedvosmisleno predstavlja vrlo snažnu vrijednost, postiže se metodom većinskog glasanja i primjenom doktrine res iudicata. ${ }^{2}$ Smerdel navodi kako se do istine dolazi kroz suprotstavljanje argumenata i kontradiktornost, jer nijedan pravni propis nije tako jasan i iscrpan da se u slučaju kad je potrebno donijeti tešku odluku ne bi mogao tumačiti različito i nijedna istina nije takva da je ne bi trebalo preispitati. ${ }^{3}$

Osnovna karakteristika sudske nezavisnosti je pravo sudije da slobodno i nezavisno od bilo koga izrazi i javno saopšti svoje pravno mišljenje, ali kada odlučuje kolektivno sudsko tijelo, odluka - ako nije jednoglasna - predstavlja mišljenje većine koja je za nju glasala i u toj odluci nema mišljenja sudije koje se

1 Mr Hamdija Šarkinović, sudija Ustavnog suda Crne Gore u penziji

2 J. Alder, "Dissents in Courts of Last Resort: Tragic Choices?", Oxford Journal of Legal Studies, v. 20, no. 2, 2000, p. 222.

3 B. Smerdel, "O sudskoj slozi i izdvojenim mišljenjima", Informator, br. 5944, 2011, str. 3. 
razlikuje od većinskog. Time se otvara pitanje što je s pravom sudije da izrazi i javno iznese svoje pravno mišljenje, što dovodi u pitanje njegovu sudijsku nezavisnost. U većini pravnih sistema taj problem je riješen tako što je u sudske postupke uveden institut izdvojenog mišljenja, čija je primjena otvorila niz drugih pitanja kojima se još uvijek bave i pravna praksa i pravna teorija. Institutom izdvojenog mišljenja puno se više bavi pravna teorija u državama utemeljenim na common law sistemu u odnosu na države kontinentalnog prava. Institut izdvojenog mišljenja bio je kroz istoriju više puta osporavan, preispitivan, napušten i ponovo prihvaćen kao sastavni dio procesa donošenja sudskih odluka. ${ }^{4}$

Mišljenje manjine, ili izdvojeno mišljenje, ili glasanje protiv (njemački abweichende Meinung, Sondervotum, francusko mišljenje disidente) jeste mišljenje koje iznosi jedan sudija ili nekoliko sudija koji se ne slažu s odlukom koju je u tom slučaju donijela većina. Takvo odvojeno izraženo mišljenje može se razlikovati od mišljenja većine zbog svog obrazloženja ili obrazloženja zaključka, ${ }^{5}$ a u angloameričkoj pravnoj literaturi razlikuju se izdvojeno mišljenje i mišljenje izdvojenog mišljenja. ${ }^{6}$ Neslaganje u sprovođenju pravde može označiti neslaganje jednog ili više članova vijeća s većinskim mišljenjem. Neslaganje sudije može, ali ne mora, proizvesti suprotno mišljenje, odnosno formulisanje neslaganja kao izdvojeno mišljenje. U Njemačkoj se na Saveznom ustavnom sudu (Bundesverfassungsgericht, BverfG) razlikuje supstancija izdvojenog mišljenja (abweichende Meinung) i njegova prezentacija kao mišljenja, odnosno procesni oblik (Sondervotum). ${ }^{7}$ Saglasno mišljenje (njemački abweichende Meinung nur in der Begründung, francusko opion concordate) predstavlja mišljenje u kojem se sudija slaže s rezultatom presude, ali ne i s obrazloženjem. ${ }^{8}$

Izdvojeno mišljenje je recept koji je neophodan da bi bilo koji sud bio zdrav i dok sud ima jednog ili dvojicu sudija s dubokim ubjeđenjima i snažnim osjećanjima koji se ne plaše da izraze svoje stavove, drugim članovima tog određenog suda, po inerciji, usljed lošeg prosuđivanja ili nedostatka ispitivanja, neće biti dozvoljeno da se opuste u stanju uma ekvivalentnom staroj i lažnoj ideji da "ono što je bilo dovoljno za naše djedove, dovoljno je i za nas". Sve dok postoji neistomišljenik u bilo kom sudu, ostale će sudije pažljivo ispitivati svoje stavove o bilo kojoj temi. Ako izdvojeno mišljenje ukaže na greške u većinskom mišljenju, neminovno će doći do promjene propisa ili pravnog stava i uticati na poboljšanje pravnog sistema. Ako sudija koji nije saglasan sa stavovima većine ćuti, izbjegava dužnost ne samo u odnosu na sebe, već i širu stručnu i laičku javnost. On izbjegava dužnost u odnosu na sebe tako što neće stati i boriti se za ono u što vjeruje, izbjegava dužnost u odnosu na

4 D. Vitale, "The Value of Dissent in Constitutional Adjudication: a context-specific analysis", Review of Constitutional Studies, v. 19, no. 1 (2014), str. 7, 3. januara 2016.

5 K. H. Milgramm, Separete Opinium und Sondervotum in der Rechprechung des Supreme Court of the Unites States und des Bundesverfassungsgerichts, Berlin, Duncker \& Humbolt, 1985, p. 59.

6 Black's Law Dictionary, St. Paul, Minn.: West Publishing Co, 1979.

7 K. Nadelman, "The Judical Dissent", American Journal of Comparative Law, vol. 8, 1959, p. 417.

8 J. Laffranque, "Dissenting Opinion and Judicial Independence", Juridical International Law Review, University of Tartu, VIII/2003, pp. 162-172. 
širu javnost koja je, u većini slučajeva, odgovorna za njegovo imenovanje za sudiju kao i njegov dalji položaj u sudu. Javnost ima pravo da zna koji su stavovi sudija i uvjerenja u različitim oblastima zakona te da je dužnost sudije da vidi jesu li ti stavovi i uvjerenja stvar javne evidencije putem objavljenih izdvojenih mišljenja. ${ }^{9}$

Izdvojeno mišljenje igra zaštitnu ulogu kada je u pitanju nepravedno zakonodavstvo ukazujući na to gdje je takvo zakonodavstvo neustavno. Sprečavanje da zakoni koje donosi zakonodavno tijelo uveliko ulaze u prava pojedinca zagarantovana Ustavom jasna je, ali često zanemarena, dužnost sudova. Izdvojeno mišljenje služi i kao kočnica reakcionarnim tendencijama nekih sudija da drže na snazi protivustavno donijeto zakonodavstvo u cilju unapređenja javnog zdravlja, morala i blagostanja. Odličan primjer izdvojenog mišljenja koje je kasnije postalo zakon može se naći u slučaju Minersville School District (Minersville školski okrug) protiv Gobitis, gdje je Vrhovni sud Sjedinjenih Država smatrao, uz izdvojeno mišljenje sudije Stone, da statut koji zahtijeva obavezni pozdrav zastave od strane školske djece nije protivustavno ograničavao slobodu vjeroispovijesti. Ovaj slučaj je odbačen četiri godine kasnije u predmetu Odbor za obrazovanje Zapadne Virdžinije protiv Barnetta, koji je slijedio obrazloženje neslaganja sudije Stonea u slučaju Minersville. Ovdje bi se mogli izložiti i mnogi drugi primjeri. ${ }^{10}$

\subsection{Vrste izdvojenog mišljenja}

Teodor Antić razlikuje tri vrste izdvojenih mišljenja u praksi ustavnog sudstva: ${ }^{11}$

kada sudija prihvata odluku većine o meritumu, ali nije saglasan s razlozima na kojima je utemeljena (concurring opinion) kada se sudija protivi i odluci o meritumu i obrazloženju (dissenting opinion), ${ }^{12}$ u common law državama postoji i tzv. dubitante koju sudija stavlja kada nije uvjeren u ispravnost odluke, ali ne u tolikoj mjeri da bi izdvojio svoje mišljenje. ${ }^{13}$

U Crnoj Gori, kao i u Repblici Srbije, do sada se niko nije bavio pitanjem izdvojenih mišljenja, niti je objavljen bilo koji stručni rad na ovu temu. ${ }^{14}$

9 J. W. Carter, Dissenting Opinions, 4 Hastings L.J. 118 (1953).

10 Ibid., str. 119.J.

11 T. Antić, "Izdvojeno mišljenje u sudskim postupcima i praksa Ustavnog suda Republike Hrvatske", Zbornik Pravnog fakulteta Sveučilištva u Rijeci, br. 2/2016, str. 840-841.

12 B. Smerdel, Ustavno uređenje europske Hrvatske, II izmijenjeno i dopunjeno izdanje, Narodne novine, Zagreb, 2012, str. 477.

13 Black's, op. cit., str. 537. Jedan je od poznatijih primjera predmet Feldman v. Allegheny Airlines (spor oko naknade štete nastale smrću u vazduhoplovnoj nesreći) koji se vodio pred američkim Saveznim žalbenim sudom za Drugu sudsku oblast (Unites States Court of Appeals for the Second Circuit), u kojem je istaknuti sudija Friendly kao član tročlanoga sudskog vijeća, u presudi izričito naveo kako ozbiljno sumnja u ispravnost donesene odluke, ali ipak glasa saglasno većini, jer se ta sumnja temelji samo na njegovoj intuiciji i ne može dokazati njenu opravdanost. Felman v. Allegheny Airlines, tač. 34.

14 Vidi: M. Šuković, Ustavno pravo, CID, Podgorica, 2009, str. 405-407; J. Đorđević, Ustavno pravo, Savremena administracija, Beograd, 1976, str. 785-786; R. Marković, Ustavno pravo i političke institucije, Službeni glasnik, Beograd, 1995, str. 674-675; V. Petrov, D. Simović, Ustavno pravo, Službeni glasnik, Beograd, 2018, str. 425-427. 
U prvom slučaju sudija se slaže s odlukom u meritumu, s izrekom, ali se u određenoj mjeri ne slaže s njenim obrazloženjem. Ovdje se radi o "potvrđujućem izdvojenom mišljenju", ${ }^{15}$ koje odgovara engleskom concurring opinion u kojem sudija svoj glas za donesenu odluku obrazlaže razlozima koji se razlikuju od onih izraženih u obrazloženju odluke. ${ }^{16} \mathrm{U}$ ovakvom posebnom mišljenju sudija iznosi svoje posebne razloge za donošenje sudske odluke, pri čemu može izraziti neslaganje s pojedinim djelovima obrazloženja, a može iznositi posve nove razloge $\mathrm{u}$ prilog donesene odluke koji nedostaju u obrazloženju i isto dopuniti. S obzirom na izloženo razlikujemo "izdvojeno konkurentno mišljenje", kojim sudija upućuje na druge razloge iz kojih je glasao za odluku u odnosu na razloge iz obrazloženja, i "izdvojeno odobravajuće (potvrđujuće) mišljenje", kojim sudija dopunjuje razloge odluke. ${ }^{17} \mathrm{U}$ drugom slučaju sudija se ne slaže s većinskim mišljenjem (engl. majority opinion, main opinion) i glasanje protiv odluke obrazlaže u posebnom pisanom mišljenju u kojem navodi razloge protiv donošenja odluke o sadržaju kako je to utvrdilo sudsko tijelo (engl. dissenting opinion ili skraćeno dissent). ${ }^{18}$

Pravni sistemi u kojima je sudijama dopušteno izjavljivanje izdvojenog mišljenja razlikuju se s obzirom na pravila njihovog objavljivanja u javnosti odnosno dostupnosti subjektima izvan suda, pa se razlikuju dva osnovna tipa sistema: sistemi u kojima se izdvojeno mišljenje objavljuje zajedno s predmetnom sudskom odlukom i sistemi u kojima se sudskoj odluci pridodaje pisano izdvojeno mišljenje samo uz primjerke koji se dostavljaju strankama u postupku.

Institut izdvojenog mišljenja u pravnom sistemu Crne Gore, kao i u pravnom sistemu Republike Hrvatske ima dvostruko značenje: u širem smislu obuhvata podudarno izdvojeno mišljenje i suprotno izdvojeno mišljenje (u značenju engleskog izraza separate opinion), a u užem smislu ono označava samo suprotno izdvojeno mišljenje (u značenju engleskog izraza dissenting opinion). ${ }^{19}$

Izdvojena mišljenja u pravnom sistemu Crne Gore mogu se izjaviti na sve odluke Ustavnog suda u kojima je nadležan Ustavni sud, shodno članu 149 st. 1 Ustava Crne Gore: ${ }^{20} 1$ ) o saglasnosti zakona s Ustavom i potvrđenim i objavljenim međunarodnim ugovorima; 2) o saglasnosti drugih propisa i opštih akata s Ustavom i zakonom; 3) o ustavnoj žalbi zbog povrede ljudskih prava i sloboda zajamčenih Ustavom, nakon iscrpljivanja svih djelotvornih pravnih sredstava; 4) je li predsjednik Crne Gore povrijedio Ustav; 5) o sukobu nadležnosti između sudova i drugih državnih organa, između državnih organa i organa jedinica lokalne samouprave i između organa jedinica lokalne samouprave; 6) o zabrani rada političke partije ili nevladine organizacije; 7) o izbornim sporovima i sporovima u vezi s referendumom koji

15 J. Crnić, Komentar ustavnog zakona o Ustavnom sudu Republike Hrvatske, Zagreb, Narodne novine, 2002, str. 60.

16 Black's, op. cit., str. 309 i 1125.

17 J. Crnić, op. cit., str. 60.

18 Black's, op. cit., str. 506 i 1125.

19 T. Antić, op. cit., str. 842.

20 Ustav Crne Gore, član 149. 
nijesu u nadležnosti drugih sudova; 8) o saglasnosti s Ustavom mjera i radnji državnih organa preduzetih za vrijeme ratnog i vanrednog stanja.

Izdvojena mišljenja u pravnom sistemu Crne Gore nijesu dozvoljena na odluke i rješenja Ustavnog suda kojima se obustavlja izvršenje pojedinačnog akta odnosno radnje, ukida mjera obustave ili odbacuje zahtjev za obustavu izvršenja pojedinačnog akta ili radnje.

\section{ISTORIJSKO-KOMPARATIVNI ASPEKT}

\subsection{Nastanak i razvoj izdvojenog mišljenja}

Većinsko odlučivanje počinje se primjenjivati u sudovima u common law sistemima, a u naučnoj literaturi kao jedan od najranijih predmeta u kojima je izričito priznata neizbježnost neslaganja sudije često se navodi predmet Grindley $v$. Barker iz 1798. godine, koji se vodio pred tadašnjim engleskim Kraljevskim sudom (Court of King's Bench). Naime, sud je izrazio stav da se odluke koje se ne tiču striktno privatnih odnosa stranaka, već se odnose na opšta pitanja ${ }^{21}$ odnosno pitanja od javnog interesa, ako okolnosti u konkretnom slučaju ne nalažu drukčije, donose većinom glasova, a odluka koju je donijela većina sudija čini odluku suda u cjelini, bez obzira na manjinu sudija koji se s njom nijesu složili, po načelu ubi major pars, ibi totum (gdje je veći dio, ondje je i cjelina). ${ }^{22}$

Istorijskom razvoju instituta izdvojenog mišljenja posebno je doprinijela praksa Vrhovnog suda SAD-a čiji uticaj oduvijek daleko prelazi granice države, a čija moć proizlazi iz njegovih ovlašćenja i položaja koje zauzima među visokim državnim vlastima, o čemu je pisao još Tocqueville, navodeći kako je riječ o sudu koji se "nalazi iznad svakoga poznatog suda i prema naravi svojih prava i prema vrsti ljudi koji popadaju pod njegovu nadležnost" te čija su "ovlaštenja gotovo u potpunosti politička, premda mu je ustrojstvo u potpunosti pravosudno". ${ }^{23}$ Pritom se često ističe kako glavni temelj njegova političkog legitimiteta leži u njegovoj povezanosti s idealom vladavine prava. Isti autor objašnjava "da pravnici imaju dvije mogućnosti: ili da sami sebe uvjere kako je ono što moraju braniti istina ili da svoje argumente izvode u ponovnoj savjesti kako je istina relativna i kako je njihova dužnost zastupati određenu stvar bez obzira na istinu". ${ }^{24}$

U SAD-u, s obzirom na ustavno sudstvo, tako postavljen sistem bio je izuzetno uspješan, jer je kod sudija podigao ambiciju i osjećaj odgovornosti, ojačao kvalitet

21 A. Lynch, "Is Judicial Dissent Constitutionally Protected", Macquarie Law Journal, v. 4, 2004, str. 83, bilj. 10, 16. januara 2016.

22 I. M. Cameron, "Majority Rule; the Development of General Principle in Cases on Chartered Corporations", Melbourne University Law Review, 6, v. 15, no. 1, 1985, p. 122.

23 A. de Tocqueville, O demokraciji u Americi, Informator, Zagreb, 1995, str. 67.

24 B. Smerdel, "O sudskoj slozi i izdvojenim mišljenjima", op. cit. str. 3 
presuda, spriječio stagniranje judikature i omogućio progres te razvio umjesnu kritiku presude. ${ }^{25}$

Tradicija tajnosti vijećanja u kontinentalnom dijelu Evrope je nešto poput mita, jer zapravo postoji nekoliko istorijskih primjera suprotne prakse. U španskoj pravnoj tradiciji neslaganje datira od 15. vijeka, od uredbe iz Medine koja je dopuštala da se zasebna mišljenja, nazvana voto reservado, registruju u tajnoj neobjavljenoj knjizi. ${ }^{26}$ Ovo je pravilo bilo sačuvano zakonima o građanskom i krivičnom postupku 1881. i 1882. godine, a ostalo je na snazi do 1985. godine, kad je upotreba neslaganja proširena na čitav pravosudni sistem. ${ }^{27} \mathrm{U}$ Italiji, prije ujedinjenja zemlje i usvajanja francuskog modela, neki lokalni zakoni nadahnuti su španskim zakonima, pa su u Napuljskom Kraljevstvu, državama Este i Toskane bila podnesena suprotna mišljenja. ${ }^{28} \mathrm{U}$ Njemačkoj, u pokrajini Baden, oni koji se nijesu slagali bili su objavljeni do sredine 19. vijeka, dok se u državi Württemberg praksa javnog glasanja zadržala sve do Drugog svjetskog rata. ${ }^{29}$

Zapadna Njemačka postala je prva evropska zemlja koja je zakonski prepoznala izdvojeno mišljenje u svom pozitivnom zakonu. Tokom izrade Zakona o sudstvu (Gerichtsverfassungsgesetz) 1877. godine iznijet je prijedlog da se dopusti izdvojeno mišljenje, ali je odbijen s obrazloženjem da bi se objavljivanje neslaganja smatralo "nespojivim s autoritetom sudova i dobrim odnosima između sudija, što bi podstaklo sujetu i osporavanje. ${ }^{30}$

Pitanje se opet pojavilo tokom stvaranja Saveznog ustavnog suda nakon Drugog svjetskog rata. Kod ove tačke, iako je blagotvorno dejstvo objavljivanja zasebnih mišljenja priznato od strane radnog tijela ustavnog zakona, njegovo je uvođenje $u$ početku odbijeno s obrazloženjem da "povjerenje u pravdu, a posebno u ustavnu pravdu još nije bilo dovoljno razvijeno [...] da bi se spriječila mogućnost parnice $s$ političkog aspekta do kojih mogu doći javne reakcije [...] ako, u parnici koja uključuje politička pitanja, sam sudac utvrdi da bi bilo moguće odlučiti drugačije". Uprkos ovom početnom odbijanju zakonodavstva da dopusti objavljivanje neslaganja, Savezni ustavni sud k je stupio u septembru 1951. godine donio srazmjeru između

25 I. Krbek, Ustavno sudovanje, Zagreb, Jugoslavenska akademija znanosti i umjetnosti, 1960, str. 86. O izdvojenim mišljenjima u Americi, Kanadi i Australiji vidi: T. Antić, op. cit., str. 844-845.

26 Chapter XIV of the Ordenanzas de Medina, in Novíssima Recompilación de las Leyes de España, Tomo II, Boletín Oficial del Estado 350, 1976.

27 L. Luatti, Profili costituzionali del voto particolare. L'esperienza del Tribunale Costituzionale Spagnolo 163-69 (Giuffrè ed.), 1995.

28 V. Denti, "Per il ritorno al "voto di scissura" nelle decisioni giudiziarie", in Le opinioni dissenzienti dei giudici costituzionali ed internazionali 1, 3-6 (Costantino Mortati ed.), 1964.

29 L. P. Oneto, Le opinioni dissenzienti dei giudici della Corte costituzionale Tedesca, in Annali della facoltà di scienze politiche di Genova 1083, 1087 (1976-77).

30 Von Mehren, supra note 12, at 209 n. 42. 
Mr. Hamdija Šarkinović: Izdvojeno mišljenje u praksi Ustavnog suda Crne Gore Zbornik radova Pravnog fakulteta u Splitu, god. 58, 3/2021, str. 683-709

glasova za i protiv, poznatu javnosti, prvi put u odluci od 8 decembra $1952^{31}$ i deset dana kasnije sudija Willi Geiger objavio je izdvojeno mišljenje. ${ }^{32}$

Sud je postupno promijenio svoju praksu, dopustivši na kraju objavljivanje anonimnog izdvojenog mišljenja. Godine $1967 .{ }^{33}$ Drugo odjeljenje (Senat) Suda uspostavilo je praksu otkrivanja broja glasova za i protiv. Prijedlog za izmjenu statuta o Bundesverfassungsgericht predložila je Savezna vlada u decembru 1969. godine, što je Bundestag i usvojio godinu dana kasnije i regulisao detaljno u Poslovniku Suda, izmijenjenom u decembru 1971. Prema novim pravilima Sud ima mogućnost objavljivanja izdvojenih i saglasnih mišljenja (Sondervotum) te otkrivanja broja glasova za i protiv na anoniman način. ${ }^{34}$

U Evropi među ustavnim sudovima raste trend dopuštanja izdvojenih mišljenja, iako se njihova primjena razlikuje od države do države. Izdvojena mišljenja mogu imati oblik izdvojenih, ali i saglasnih mišljenja, tj. mogu izražavati neslaganje samo uz obrazloženje konačne odluke. Čak se i u kontinentalnim, građanskopravnim sistemima, izdvojena mišljenja više ne smatraju izuzetkom od pravila tajnosti pojedinačnih glasova. ${ }^{35}$ Među državama članicama Savjeta Evrope 36 izričito regulišu izdvojena mišljenja (uključujući vrhovne sudove u državama u kojima ne postoje ustavni sudovi), a jedanaest ih ne dozvoljava ili nema odgovarajuće odredbe. U većini država članica Savjeta Evrope (naime, više od 20 država) sudije ustavnih sudova imaju pravo da podnesu izdvojena mišljenja kad god nijesu saglasni s presudom suda (to uključuje i države u kojima sudije vrhovnog suda $-\mathrm{u}$ određenoj mjeri - imaju slične funkcije kao sudije ustavnog). Neke države članice EU zabranjuju izdvojena mišljenja ili nemaju odgovarajuće odredbe i odbacuju ovu praksu (Austrija, Belgija, Francuska, Italija, Irska, Luksemburg i Malta). ${ }^{36}$

Što se tiče Evropskog suda za ljudska prava, Evropska konvencija o ljudskim pravima i Pravila Suda (Evropskog suda za ljudska prava) izričito pominju izdvojena mišljenja (vidi u daljem tekstu). Staviše, ova mišljenja igraju važnu ulogu u praksi Suda. Situacija je sasvim drugačija u Sudu pravde Evropske unije, gdje izdvojena mišljenja nijesu dozvoljena. ${ }^{37}$

31 K. H. Nadelmann, Non-Disclosure of Dissents in Constitutional Courts: Italy and West Germany, 13 AM. J. COMP. L. 268, 272 (1964).

32 J. Luther, "L'esperienza del voto dissenziente nei paesi di lingua tedesca", in Politica del diritto 241, 244, 1994.

33 P. W. Amram, The Dissenting Opinion Comes to the German Courts, 6 AM. J. COMP. L. 108, 110 (1957). A well-known example is the Spiegel-decision. Vidjeti: Bundesverfassungsgericht [BVerfGE - Federal Constitutional Court], Case No. 1 BvR 586/62, 610/63, 512/64, DEJURE 20, 162 (Aug. 5, 1966), http://dejure.org/dienste/vernetzung/rechtsprechung?Text=BVerfGE\%2020\%2C\%20162\&Suche $=\mathrm{BVerfGE} \% 2020 \% 2 \mathrm{C} \% 20162$.

34 K. Kelman, "Dissenting Opinions in Constitutional Court, German Law Journal, 14, 135/1371.

35 Studija koju je pripremio Generalni direktorat za spoljne politike Evropskog parlamenta, Izdvojena mišljenja na vrhovnim sudovima država članica (2012), 30f (u daljem tekstu Evropski parlament, Izdvojena mišljenja (2012)).

36 T. Antić, op. cit., str. 846; Evropski parlament, Izdvojena mišljenja (2012), posebno 6, 17.

37 J. Laffranque, "Izdvojeno mišljenje na Evropskom sudu pravde - Mogući doprinos Estonije demokratizaciji pravosudnog sistema Evropske unije", Juridica International, IKS 2003, str. 14. 
Države s pravnim sistemima zasnovanim na kontinentalnoevropskom modelu, poput većine Evrope, Latinske Amerike i djelova Dalekog istoka, imaju ustavne sudove koji su odvojeni od redovnih sudova. U zemljama običajnog prava, koje uključuju većinu engleskog govornog područja (Irska, Ujedinjeno Kraljevstvo, Sjedinjene Države), kao i Kipar ${ }^{38}$ i Izrael, o ustavnim pitanjima (ili, u slučaju Izraela, kvaziustavna pitanja ${ }^{39}$ ) obično - ali ne isključivo - odlučuju redovni sudovi u kontekstu konkretnih slučajeva. Opseg ispitivanja takođe uključuje sljedeće skandinavske (i nordijske) zemlje: Dansku, Finsku, Norvešku i Švedsku, gdje sudije vrhovnog suda imaju - u određenoj mjeri - slične funkcije kao i sudije ustavnih sudova. Isto se odnosi i na Grčku. ${ }^{40}$

Države običajnog prava, koje slijede britansku praksu odlučivanja o seriatim mišljenjima, nude sudijama najviši nivo transparentnosti i slobode izražavanja. Odluke donosi većina, a odgovornost za sastavljanje većinske presude dodjeljuje se sudiji u većini. Otkriće se njegovo ili njeno ime, kao i imena sudija koje su saglasne. Saglasna ili suprotna mišljenja/presude podnosi svaki sudija, pojedinačno ili kolektivno, ako presuda nije donijeta jednoglasno. Izdvojena mišljenja/presude praktično se automatski otkrivaju u ovom sistemu, koji koriste, na primjer, Vrhovni sud Ujedinjenog Kraljevstva, Vrhovni sud SAD-a, Vrhovni (Ustavni) sud Kipra ${ }^{41}$ i Vrhovni sud Izraela. ${ }^{42}$ Irski pravni sistem služi kao rijedak izuzetak, jer - iako se pravni sistem zasniva na običajnom pravu - Ustav izričito zabranjuje objavljivanje izdvojenih mišljenja u većini ustavnih pitanja. Dok obične sudije i Vrhovni sud Irske u vršenju svoje redovne nadležnosti mogu davati izdvojena mišljenja, ${ }^{43}$ ustavni slučajevi slijede restriktivni postupak. Prema članovima 26 i 34 Ustava Vrhovni sud, kada odlučuje o ustavnosti bilo kog zakona na zahtjev predsjednika, ili po žalbi nižeg suda, donosi jedinstveno mišljenje. Nijedno drugo mišljenje, "bilo da je saglasno ili izdvojeno, neće biti izrečeno, niti će postojanje bilo kog drugog mišljenja biti objelodanjeno".

Od preostalih 56 zemalja (61 država članica Venecijanske komisije bez Kipra, Irske, Izraela, Ujedinjenog Kraljevstva i Sjedinjenih Država) 12 nema odredbu o

38 Vrhovni sud nadležan je za ispitivanje ustavnosti bilo kog zakona ili bilo kog sukoba moći ili nadležnosti koji nastane između bilo kojih organa ili vlasti Republike. Pored toga, Vrhovni sud saslušava i određuje bilo kakav pravni lijek predsjednika Republike u vezi s kompatibilnošću s ustavom bilo kog zakona koji je donio Predstavnički dom, vidjeti http://www.supremecourt.gov.cy/judicial/sc.nsf/ DMLSCourt_en/DMLSCourt_en?OpenDocument

39 Izrael nema pisani ustav, već takozvane osnovne zakone, a Vrhovni sud je smatrao da se drugi zakoni mogu poništiti ako su u suprotnosti s tim zakonima; vidjeti United Bank Mizrahi protiv Migdal Cooperative Village [1995] IsrSC 49 (4) 221, http://versa.cardozo.yu.edu/opinions/united-mizrahi-bankv-migdal-Cooperative-Village

40 Evropski parlament, Izdvojena mišljenja na vrhovnim sudovima država članica, str. 23.

41 Nicolatos, M. M., Parparinos, L., Hadjiprodromou, M., Administrative justice in Europe: The Supreme Court of Cyprus, 2018, 2; na http://www.aca-europe.eu/en/eurtour/i/countries/cyprus/cyprus_ en.pdf, str. 27.

42 Vidjeti npr. United Bank Mizrahi protiv Migdal Cooperative Village [1995] IsrSC 49 (4) 221, http://versa.cardozo.yu.edu/opinions/united-mizrahi-bank-v-migdal-cooperative-village

${ }^{43}$ U nekim slučajevima mogu čak slijediti praksu seriatim mišljenja: vidjeti G. P. J. McGinley, "The Search for Unity: The Impact of Consensus Seeking Procedures in Appellate Courts", Adelaide Law Review, br. 11/1987, 203-214; J. Laffranque, op. cit., 165. 
Mr. Hamdija Šarkinović: Izdvojeno mišljenje u praksi Ustavnog suda Crne Gore Zbornik radova Pravnog fakulteta u Splitu, god. 58, 3/2021, str. 683-709

izdvojenim mišljenjima ili izričito zabranjuje izdvojena mišljenja kada je u pitanju ustavna nadležnost (Alžir, Andora, Austrija, Belgija, Francuska, Italija, Lihtenštajn, Luksemburg, Malta, San Marino, Švajcarska, Tunis). Velika većina država članica Venecijanske komisije dozvoljava izdvojena mišljenja u ustavnoj nadležnosti. Druga mogućnost da se otkrije da odluka nije usvojena jednoglasno jeste prosto otkrivanje raspodjele glasova u odluci. ${ }^{44}$ Ovo će biti detaljnije razmotreno u nastavku.

\subsection{Evropske države u kojima nije dozvoljeno izdvojeno mišljenje}

Belgijski pravosudni sistem inspirisan je principom tajnosti rasprava, koji se tumači kao zabrana objavljivanja pojedinačnih mišljenja. Kasacioni sud je prepoznao da je tajnost razmatranja princip belgijskog zakona i nedavno je potvrdio da su sudije dužne da ga sačuvaju. Štaviše, sud je smatrao da je svako kršenje takve tajne, uključujući objavljivanje pojedinačnih stavova sudija o odluci koju treba donijeti, kažnjivo u skladu sa čl. 458 krivičnog zakona.

Iako zakletva koju belgijske sudije polažu ne pominje izričito tajnost razmatranja, ${ }^{45}$ sudovi, uključujući i Ustavni sud, striktno slijede princip: izdvojena mišljenja se nikada ne objavljuju. ${ }^{46}$

Budući da ne postoji holandski ustavni sud,${ }^{47}$ jedina relevantna praksa u pogledu izdvojenih mišljenja jeste praksa redovnih sudova. Holandski sudovi tradicionalno slijede princip tajnosti razmatranja, koji je takođe odobren zakonodavstvom i tumači se kao zabrana objavljivanja pojedinačnih mišljenja. ${ }^{48}$ Međutim, o principu se raspravljalo više puta. Iako se čini da reforma nije na putu, pridržavanje tajnosti nije nekontroverzno.

Austrija se strogo pridržava tajnosti razmatranja, kako na običnom, tako i na ustavnom nivou. Prema zakonu o Ustavnom sudu njegova razmatranja i glasanja nijesu javna. Slična zabrana utvrđena je i u zakonu o upravnom sudu, a i ostali sudovi slijede isti princip. Iako je sudijama neistomišljenicima dozvoljeno da imaju svoje

44 Vidjeti, stav 30 (2) Zakona o Saveznom ustavnom sudu Njemačke.

45 B. Nelissen, Judicial Loyalty Through Dissent or Why The Timing is Perfect for Belgium to Embrace Separate Opinions", Electronic Journal of Comparative Law, vol. 15.1, 2011; Čl. 2, Decret du 20 juillet 1831.

46 Ustavni sud u početku se zvao "Arbitražni sud" i bio je nadležan samo za suđenje u slučaju sukoba između različitih državnih vlasti; prema nekim autorima, to je objasnilo odluku o zabrani izdvojenih mišljenja, s obzirom na to da je glavna funkcija Suda bila da pacifikuje različite institucije. Međutim, nadležnosti Suda vremenom su proširivane (i njegovo je ime u skladu s tim izmijenjeno u Cour Constitutionnelle) bez ikakvih promjena vezanih za tajnost njegovih rasprava. Vidjeti M.-F. Rigaux, $L a$ Cour constitutionnelle et les opinions séparées, 17. februara 2012, dostupno na http://www.justice-enligne.be/article404.html.

47 Holandski pravni sistem ne predviđa bilo koji oblik ocjene ustavnosti - upravo suprotno: član 120 Ustava izričito zabranjuje sudsku kontrolu kompatibilnosti zakona donijetih u Parlamentu s Ustavom. Vidjeti P. van Dijk, "Constitutional review in the Netherlands", u Liber Amicorum Antonio La Pergola, Istituto Poligrafico e Zecca dello Stato, 2009; G. van der Schiff, "Constitutional review by the judiciary in the Netherlands: A bridge too far?" German American Law Journal, vol. 11.2, 2010.

48 M. Malsch, Democracy In the Courts : Lay Participation In European Criminal Justice Systems. Farnham: Ashgate, 2009, p. 88. 
stavove i zbog toga se njihovi razlozi evidentiraju, oni se drže u tajnosti: samo viši sudovi (u slučaju redovnih sudova) i kolege imaju pristup privatnim registrima. ${ }^{49}$

Ova tradicija tajnosti, međutim, nije ostala bez osporavanja. Od šezdesetih godina prošlog vijeka naučnici su to više puta dovodili u pitanje i čini se da mnogi autori podržavaju reformu, dok je Ustavni sud u cjelini protiv takve promjene. ${ }^{50}$

Francuski pravosudni sistem pridržava se principa tajnosti vijećanja, koje je eksplicitno protumačeno kao zabrana objavljivanja neslaganja. Francuski Conseil d'État prepoznao je da je princip tajnosti opšte načelo francuskog javnog prava, zabranjujući čak i predstavljanje a odluku kao "jednoglasnu", jer bi to rezultiralo otkrivanjem pojedinačnog glasanja svakog od sudija koji učestvuje u vijeću. ${ }^{51}$

Italija slijedi princip tajnosti vijećanja i pojedinačnih mišljenja i u redovnom sudstvu i na ustavnom nivou, jer nijedan sudija ne smije objaviti izdvojeno mišljenje. Načelo tajnosti zakonom je izričito priznato, kako u građanskom tako i u međunarodnim krivičnim suđenjima i njegova važnost je takva da onaj sudija koji ga ne poštuje odgovara za krivično djelo. Međutim, od 1988. godine (kad je donesen novi zakon o građanskoj odgovornosti sudija) neslaganje i osnovi prema tome mogu se evidentirati na zahtjev neistomišljenika, ali se čuvaju u zapečaćenoj koverti. Isti principi važe i pred Kasacionim sudom i pred Ustavnim sudom.

U Luksemburgu i Malti ni u redovnom ni ustavnom sudstvu nije dozvoljeno izdvojeno mišljenje. ${ }^{52}$

\subsection{Evropske države u kojima je dozvoljeno izdvojeno mišljenje}

SR Njemačka je jedan od najpoznatijih primjera zemlje koja slijedi građanskopravnu tradiciju, ali omogućava ustavnim sudijama da daju izdvojena mišljenja. Iako su sudije koje sjede u redovnim sudovima dužne da poštuju tajnost razmatranja i glasanja, ustavne sudije predstavljaju izuzetak od ovog pravila.

Istorijski gledano, Njemačka se nije uvijek pridržavala principa tajnosti; međutim, od XIX vijeka to je postalo opšte pravilo. Kad je stvoren Ustavni sud, nijesu bila predviđena izdvojena mišljenja: odbijen je nacrt prijedloga kojim bi se sudijama u manjini dalo pravo da objavljuju svoje suprotno mišljenje. Izdvojena mišljenja pojavila su se kroz praksu. U nekim slučajevima Sud je objavio rezultate glasanja, kršeći privid jednoglasnosti, čuvajući u tajnosti identitet i razloge sudija

49 T. Antić, op. cit., str. 846.

50 B. Bierlein, "The constitutional legal protection of fundamental rights: possibilities and scope of access of an individual", rad predstavljen na Svjetskoj konferenciji o ustavnoj pravdi 2011. godine, dostupan na http://www.venice.coe.int/VCCJ/Rio/Papers/AUT_Bierlein_E.pdf, str. 10; 1998. godine održana je parlamentarna istraga o izdvojenim mišljenjima, što je dovelo do objavljivanja niza radova koji se bave ovim pitanjem u Journal für Rechtspolitik, n. 7/1999.

51 J.-P. Ancel, Les opinions dissidentes, dostupno na http://www.courdecassation.fr/IMG/File/ opinions_dissidentes_jp_ancel.pdf; Conseil d'Etat, 15 October 1965, in Mazel, Droit administratif, 1965, n. 377, cited in Lécuyer, op. cit., p. 199.

52 European Parliament, Dessenting Opinium in the Supreme Courts of the Member States, 2012, 19. 
Mr. Hamdija Šarkinović: Izdvojeno mišljenje u praksi Ustavnog suda Crne Gore Zbornik radova Pravnog fakulteta u Splitu, god. 58, 3/2021, str. 683-709

u manjini. Godine 1966. prvi put je donijeta odluka u odnosu 4 naprema 4 glasa: sud je stoga odlučio da u presudu uvrsti stavove obiju grupa sudija. Isto se ponovilo 1969. godine, što je na kraju dovelo do promjene zakona.

U svom trenutnom tekstu, izmijenjenom i dopunjenom 1970. godine, zakon o Ustavnom sudu izričito daje sudijama u manjini pravo da objave izdvojeno mišljenje (Sondervotum). Iako se to pravo u početku koristilo u velikoj mjeri (u prvoj godini nakon izmjena i dopuna izdato je 17 izdvojenih mišljenja od ukupno 72 presude), entuzijazam za njegovo korišćenje naknadno se smanjio. Danas se izdvojeno mišljenje priloži za približno $6 \%$ svih odluka, obično o najkontroverznijim slučajevima (koji uključuju osjetljiva politička pitanja, poput abortusa ili azila, ili složena pravna pitanja).

Ako je institucija izdvojenih mišljenja u početku bila prilično kontroverzna, ona je sada dobro prihvaćena i njena svrsishodnost se više ne dovodi u pitanje: kritike uglavnom ciljaju stil i način na koji se izrađuju izdvojena mišljenja, a ne samu instituciju. Njemački advokati saglasni su da su sudije dužne da budu lojalne sudu i vijeću čiji su dio, te da se izrazito polemična mišljenja trebaju izbjegavati. U isto vrijeme čini se da je BVerfG pronašao pohvalan kompromis između tajnosti i široke upotrebe izdvojenih mišljenja držeći se svoje tradicije kolegijalnosti u procesu donošenja odluka. Sudije ulažu napore da postignu zajedničko rješenje i usvoje jednoglasnu odluku; međutim, kada takvi napori ne uspiju, neslaganja ne treba sakriti, već se mogu objaviti, omogućavajući koherentnije obrazloženje u presudi većine i osiguravajući transparentnost. Štaviše, u nekoliko slučajeva neistomišljenici su se pokazali korisnim kao osnova na kojoj bi se mogle graditi naknadne promjene u tumačenju Ustava.

U Španiji, tradicionalnoj zemlji građanskog prava, sve sudije imaju pravo da objavljuju izdvojena mišljenja. Istorijski gledano, Španija nije slijedila tradiciju tajnosti u istoj mjeri kao i Francuska, iako je većina presuda donijeta bez ikakve mogućnosti objavljivanja izdvojenih mišljenja. S jedne strane, sudije neistomišljenici mogli bi svoj glas zabilježiti u zasebnom registru, a predsjednik tribunala se zakleo da će čuvati njegovu tajnost. Praksa takozvanog voto reservado zadržana je donedavno u Zakoniku o parničnom postupku i Zakoniku o krivičnom postupku. Glasovi i razlozi su se stoga mogli otkriti sudijama koji čine dio Vrhovnog suda samo u slučaju žalbe. S druge strane, bilo je i nekih (izolovanih) slučajeva u kojima su objavljena izdvojena mišljenja. ${ }^{53}$

Ustav iz 1978. godine izričito predviđa objavljivanje izdvojenih mišljenja zajedno s presudom Tribunal Constitucional (čl. 164): stoga je pravo ustavnih sudija da objave svoje protivne stavove uključeno u Ustav. Ovo pravilo, koje nije bilo uključeno u prvobitni nacrt Ustava, usvojeno je jednoglasno, jer se smatralo garancijom transparentnosti i ograničenjem ovlašćenja većine. Organski zakon

53 W. Mastor, op. cit., 114-117. Takođe T. Freixes, "La pratique des opinions dissidentes en Espagne", u Nouveaux Cahiers du Conseil Constitutionnel, 2000, dostupno na http://www.conseil-constitutionnel.fr/ conseilconstitutionnel/francais/nouveauk-cahiers-du-conseil/cahier-n-8/ la-pratikue-des-vievs-disidentes -enespagne.52543.html (pozivajući se na statut Ustavnog suda Druge španske republike). 
o Ustavnom sudu dalje precizira da izdvojena mišljenja uključuju i izdvojena i saglasna mišljenja. ${ }^{54}$

Naknadno, mogućnost usvajanja izdvojenih mišljenja proširena je i na redovne sudove. Od 1985. godine čl. 260 Ley Organica del Poder Judicial (Organski zakon o pravosuđu) omogućava redovnim sudijama da objavljuju svoja izdvojena mišljenja. ${ }^{55}$ Ova reforma pokrenuta je praksom ustavnih sudija, kao i davno uspostavljenom tradicijom javnih neslaganja.

Upotreba izdvojenih mišljenja španskih ustavnih sudija neprestano raste, dostigavši nivo od oko 3\% od ukupnog broja presuda u periodu od 1992. do 1993. godine i oko $4 \%$ svih presuda donijetih između 1980. i 2008. godine. ${ }^{56}$ Iako neke sudije teže da iskoriste mogućnost izrade izdvojenog mišljenja češće od drugih, predsjednici imaju tendenciju da ne objavljuju pojedinačna mišljenja tokom svog mandata, čak i kada su to ranije činili. Izdvojena mišljenja su obično priložena uz presude koje odlučuju o vrlo osjetljivim pitanjima. Prema učenjacima, upotreba izdvojenih mišljenja nije uticala na kredibilitet ili autoritet Ustavnog suda, iako je ponekad navodila medije da "politizuju" neko pitanje. U nekim slučajevima izdvojena mišljenja su naknadno postala većinsko mišljenje, vodeći ka razvoju u tumačenju zakona.

Letonija slijedi sistem centralizovane sudske revizije, s posebnim Ustavnim sudom. Iako obične sudije ne smiju objavljivati svoje neslaganje kada kolegijalno odlučuju, ustavne sudije imaju tu mogućnost. Prema Zakonu o Ustavnom sudu presude se donose većinom, a razmatranja se odvijaju in camera (bez prisustva javnosti). Međutim, svaki sudija koji je glasao protiv mišljenja izraženog u presudi "pismeno će izraziti svoje izdvojeno mišljenje koje će biti priloženo slučaju, ali neće biti objavljeno na sjednici suda" (Odjeljak 30). U skladu s Poslovnikom Suda, izdvojena mišljenja moraju biti napisana, potpisana i predstavljena predsjedavajućem sudske sjednice u roku od dvije nedjelje (najkasnije) od objavljivanja presude (pravilo 221). Iako se presude uručuju strankama u slučaju i objavljuju u Službenom listu u roku od pet dana od usvajanja, izdvojena mišljenja prvo se distribuiraju svim sudijama koje su sjedjele u odlučujućem vijeću (pravilo 222) i objavljuju se samo naknadno i sva zajedno. ${ }^{57}$

U Ujedinjenom Kraljevstvu odluke sudija tradicionalno se izdaju seriatim: sudije dostavljaju svoje pojedinačno mišljenje odvojeno, a odluke se donose većinom. Kaže se da ova praksa zavisi od činjenice da je Dom lordova tradicionalno saslušavao $6 / 2007$

${ }^{54}$ Ley Organica 2/1979 del Tribunal Constitucional, čl. 90, izmijenjen i dopunjen Ley Organica

55 Vidjeti čl. 260, Ley Organica 6/1985 del Poder Judicial; suprotno praksi u mnogim državama (npr. SAD), sve sudije moraju potpisati konačnu odluku, čak i ako nijesu saglasni. Štaviše, prema čl. 206, ako sudija izvjestilac nije saglasan s većinom, mora odbiti sastavljanje presude i napisati obrazloženo neslaganje.

56 C. Guerrero Pico, "L'opinione dissenziente nella prassi del Tribunal Constitucional spagnolo (1994-2009)", na www.cortecostituzionale.it/documenti/convegni_seminari/CC_SS_opinione_ dissenziente_12012010.pdf

57 Zakon o Ustavnom sudu, usvojen 9. juna 1996. godine, dostupan na http://www.satv.tiesa.gov. lv/?lang=2\&mid=9, i Poslovnik o radu dostupan na http://www.satv.tiesa.gov.lv/?lang=2\&mid=10 . 
žalbe nižih sudova, koji, kao i svi ostali članovi parlamentarnih odbora, imaju pravo da slobodno izraze svoje mišljenje. Proces donošenja odluka u Domu lordova nije favorizovao kolektivne odluke, jer nije postojao poseban kolegijalni postupak. Istorijski gledano, postojala su dva izuzetka od pravila koja dozvoljavaju izdvojeno mišljenje: u Sudskom odboru, gdje neslaganja prvobitno nijesu bila dozvoljena, dok se od 1966. godine može objaviti samo jedno manjinsko mišljenje i u određenim krivičnim procesima ,gdje su izdvojena mišjenja, po opštem pravilu, zabranjena. ${ }^{58}$

Sudski sistem Ujedinjenog Kraljevstva nedavno je pretrpio neke velike promjene. Zakonom o ljudskim pravima iz 1998. godine Ujedinjeno Kraljevstvo je uvelo oblik "slabe", difuzne ustavne ocjene zasnovane na ECHR (EKLJP) (a ne na nacionalnom ustavu). Pored toga, 2009. godine Apelacioni odbor Doma lordova zamijenjen je formalno nezavisnim Vrhovnim sudom. On takođe ima posljednju riječ (na nacionalnom nivou) u vezi s kompatibilnošću postojećeg zakonodavstva sa ECHR (EKLJP) i sudskom praksom ECHR (EKLJP). Vrhovni sud slijedi tradiciju seriatim odluka, čak i kad odlučuje o slučajevima zasnovanim na Zakonu o ljudskim pravima (za koje bi se moglo reći da su slučajevi ocjene ustavnosti) ${ }^{59}$ Ipak, čini se da postoje neki dokazi o novom trendu ka donošenju pojedinačnih presuda ili pojedinačnih presuda većine. Međutim, iako je prikladnost prakse izdavanja seriatim mišljenja nedavno osporena, pravo sudija da daju izdvojena ili saglasna mišljenja je van rasprave. ${ }^{60}$

U Ruskoj Federaciji član 70 Zakona o Ustavnom sudu ${ }^{61}$ predviđa usvajanje zaključnih odluka o slučaju koji se razmatra na zatvorenoj konferenciji. Sudije i druge osobe prisutne na zatvorenoj konferenciji neće imati pravo da otkriju sadržaj rasprave ili rezultate glasanja. Na osnovu člana 72 odluke se donose javnim glasanjem većinom glasova. Nije dozvoljeno da se sudije uzdrže od glasanja. Odrebom člana 76 propisano je da sudija Ustavnog suda koji se ne slaže s odlukom može pismeno izraziti svoje mišljenje. Sudija je dužan da mišljenje priloži uz materijale koji se objavljuju i uz odluku suda. Sudija koji je glasao za usvojenu odluku ili meritorn odluke, ali koji je bio u manjini kad je glasao o bilo kojem drugom pitanju ili o motivima koji stoje iza odluke, može pismeno izraziti mišljenje o neslaganju s većinom glasova sudija. Ovo pismeno neslaganje takođe će biti priloženo uz materijale slučaja i objavljeno u Biltenu Suda.

Izdvojeno mišljenje primjenjuje se i u ovim državama: Albanija, Jermenija, Azerbejdžan, Bosna i Hercegovina, Bugarska, Hrvatska, Kipar, Češka Republika, Danska, Estonija, Finska, Grčka, Mađarska, Island, Kosovo, Letonija, Moldavija,

58 T. Ingman, Engleski pravni proces, OUP 2011, str. 98.

59 Lord A. Lester, "The Impact of the Human Rights Act on Public Law", u J. Beatson, C. Forsyth and I. Hare (eds.), Constitutional Reform in the United Kingdom: Practice and Principles, Oxford: Hart Publishing, 1998, 105-107.

60 B. Hale, Presuda Vrhovnog suda, 2010, na http://www.supremecourt.gov.uk/docs/speech_100930. pdf . Stopa jednoglasnih presuda u Domu lordova između 1970. i 2009. godine iznosila je $81,2 \%$, a na Vrhovnom sudu Velike Britanije 82\%: C. Hanretty, Dissenting opinions in the UKSC, dostupna na http:// ukscblog.com/dissenting-opinons-in-the-uksc.

${ }_{61}$ Federal Constitutional Law No. 1-FKZ on the Constitutional Court (21/7/1994, amendments $8 / 2 / 2001)$. 
Monako, Norveška, Poljska, Portugalija, Rumunija, Ruska Federacija, Srbija, Slovačka Republika, Švedska, Sjeverna Makedonija, Turska, Ukrajina. ${ }^{62}$

\section{IZDVOJENO MIŠLJENJE U PRAKSI USTA VNOG SUDA CRNE GORE}

\subsection{Istorijat izdvojenog mišljenja}

Ustav SFRJ iz 1963. godine u Glavi XIII (čl. 241-251) i Ustav SRCG iz 1963. godine u Glavi XI (čl. 218-224) ne sadrže odredbe o izdvojenom mišljenju. Zakonom o Ustavnom sudu Crne Gore iz 1963. godine ${ }^{63}$ u članu 64 propisano je da Ustavni sud odlučuje većinom glasova svih članova Suda i da član Ustavnog suda ima pravo da traži da se njegovo odvojeno mišljenje unese u zapisnik ili priloži zapisniku. Poslovnik Ustavnog suda Crne Gore iz 1963. godine ${ }^{64}$ ne sadrži odredbe o načinu glasanja u Ustavnom sudu.

Ustav Republike Crne Gore iz 1974. godine u Glavi VI (čl. 409-429) propisuje nadležnost Ustavnog suda i u članu 424 st. 2 propisuje da član Ustavnog suda koji izdvoji mišljenje ima pravo i dužnost da ga pismeno izloži i obrazloži. U Ustavu Crne Gore iz 1992. godine odredbama člana 116 propisano je da Ustavni sud odlučuje većinom glasova sudija i da se odluka Ustavnog suda objavljuje zajedno s mišljenjem sudija koji nijesu glasali za odluku.

Ustavom Crne Gore iz 2007. godine ${ }^{65}$ u članu 151 st. 1 propisano je da Ustavni sud odlučuje većinom glasova svih sudija. Zakonom o Ustavnom sudu iz 2008. godine ${ }^{66}$ odredbama člana 70 , propisano je da sudija koji je glasao protiv usvojene odluke odnosno rješenja, čijoj se izreci odnosno obrazloženju protivi, ima pravo na izdvojeno mišljenje, koje je sudija dužan da usmeno najavi na nejavnom dijelu redovne sjednice, nakon donošenja odluke odnosno rješenja. Sudija koji je izdvojio mišljenje može da zahtijeva da se to mišljenje objavi zajedno s odlukom odnosno rješenjem koje se objavljuje i da je sudija dužan da, u roku od sedam dana od dana donošenja odluke odnosno rješenja, sačini pisano obrazloženje izdvojenog mišljenja i priloži ga spisima ustavnosudskog predmeta te da se nakon dostavljanja obrazloženog izdvojenog mišljenja odluka odnosno rješenje otpremaju na objavljivanje. Ako izdvojeno mišljenje nije priloženo spisima ustavnosudskog predmeta, odluka odnosno rješenje će se dostaviti na objavljivanje. Izdvojeno mišljenje dostavljeno nakon isteka propisanog roka od sedam dana prilaže se spisima ustavnosudskog predmeta. Izdvojeno mišljenje sudije odnosno sudija objavljuje se u

${ }^{62}$ Venice Commission, Council of Europe, Report on separate opinions of Constitutional Court, Strasburg, 2018, Opinion No. 932/2018.

63 Službeni list SRCG, br. 43/63.

64 Službeni list SRCG, br. 44/63.

65 Službeni list Crne Gore, br. 1/2007.

66 Službeni list Crne Gore, br. 64/08. 
biltenu u kojem je objavljena odluka odnosno rješenje povodom kojeg je mišljenje izdvojeno, kao i na web stranici Ustavnog suda.

Amandmanom XV na Ustav Crne Gore ${ }^{67}$ kojim je dopunjen član 151 Ustava Crne Gore propisano je da Ustavni sud o ustavnoj žalbi odlučuje u vijeću sastavljenom od troje sudija. Vijeće može odlučivati samo jednoglasno i u punom sazivu. Ako se u vijeću ne postigne saglasnost o ustavnoj žalbi odlučuje Ustavni sud saglasno čl. 151 st. 1 Ustava.

Zakonom o Ustavnom sudu Republike Crne Gore, ${ }^{68}$ odredbama člana 40, propisano je da svaki sudija može izdvojiti mišljenje u kojem navodi razloge zbog kojih se u potpunosti ili djelimično slaže s donijetom odlukom, ali smatra da postoje i dodatni razlozi koje je u odluci trebalo navesti, odnosno razloge zbog kojih je u potpunosti ili djelimično protiv donijete odluke, koje se zajedno s odlukom na koju se odnosi, obavezno objavljuje na internet stranici Ustavnog suda, a da sudija koji je izdvojio mišljenje ima pravo da zahtijeva da se to mišljenje objavi u "Službenom listu Crne Gore", uz odluku na koju se odnosi.

\subsection{Izdvojena mišljenja u Ustavnom sudu}

2.1. Prvo izdvojeno mišljenje u Ustavnom sudu Crne Gore ${ }^{69}$ napisano je na Odluku Ustavnog suda Republike Crne Gore U. br. 53/06 od 11. jula 2006. godine ${ }^{70}$ kojim je utvrđeno da odredbe čl. 23 i 24 Zakona o manjinskim pravima i slobodama ("Službeni list RCG", br. 31/06) nijesu u saglasnosti s Ustavom Republike Crne Gore. Svoju odluku Ustavni sud je temeljio na tome da osporenim zakonskim odredbama "nije uređen način ostvarivanja prava i sloboda..., već je istim propisano pravo pripadnika manjina,... čiji osnov nije sadržan u Ustavu Republike Crne Gore", te da takvo "propisivanje u suštini predstavlja oblik revizije Ustava..." Pored toga, osporene odredbe, po mišljenju Suda, suprotne su ustavnim odredbama kojima se propisuje da se biračko pravo ostvaruje na izborima i da je ono opšte i jednako (čl. 32 st. 2 i 4 Ustava), kao i to da nemaju uporište u članu 73 Ustava.

U razlozima izdvojenog mišljenja, između ostalog, stoji da propisivanjem dodatnog broja mandata poslanika za pripadnike manjina u lokalnom i republičkom parlamentu preko predstavnika izabranih s manjinske izborne liste nije narušen, "nasuprot izraženom stavu Suda, ni jedan ustavni princip.... A određivanje broja poslanika koji bi dobili mandate pod posebno postavljenim uslovima, takođe nije suprotno Ustavu a i međunarodnim standardima obzirom na to da se radi o specifičnoj grupi koja ima posebnu zaštitu i pitanje je politike svake države u kojoj mjeri će se ona ostvarivati".

67 Službeni list $\mathrm{CG}$, br. 38/2013.

68 Službeni list $C G$, br. 11/2015.

69 H. Šarkinović, "Pola vijeka ustavnog sudstva u Crnoj Gori", Pravni život, Beograd, 12/2013.

70 Izdvojeno mišljenje sudije Veselina Rackovića, od 11. jula 2006. godine. 
Ovo izdvojeno mišljenje uticalo je na to da se kozmetičkim izmjenama označenog Zakona s istim sadržajem uspostavi zastupljenost nacionalnih manjinskih zajednica u Parlamentu Crne Gore, na narednim izborima, koja je još na snazi.

Broj izdvojenih mišljenja u Ustavnom sudu povećan je u 2017, 2018. i 2019. godini i stalno raste. Tako 2017. godine imamo 20 izdvojenih mišljenja, ${ }^{71}$ od kojih su dva zajedničko izdvojeno mišljenje sudija Miodraga Iličkovića i Milorada Gogića i 18 izdvojenih mišljenja sudije Hamdije Sarkinovića. Ukupno tri izdvojena mišljenja objavljena su u "Službenom listu Crne Gore". U 2018. godini bilo je 16 izdvojenih mišljenja, ${ }^{72}$ a u 2019. godini sudija Hamdija Šarkinović podnio je 5 izdvojenih mišljenja. ${ }^{73}$ Ostale sudije za sedam godina rada suda nijesu podnosile izdvojena mišljenja.

2.2. U predmetu U-I br. 23/14 od 10. februara 2016. godine Ustavni sud donio je odluku o ukidanju odredbe člana 43 stav 6 Zakona o izboru odbornika i poslanika ("Službeni list Republike Crne Gore", br. 4/98, 17/98, 14/00, 9/01, 41/02, 46/02, 48/06 i "Službeni list Crne Gore", br. 46/11 i 14/14) i člana 5 stav 1 Zakona o izboru Predsjednika Crne Gore ("Službeni list Crne Gore", br 17/07). U izdvojenom mišljenju, pored ostalog, stoji: "smatrajući je, isključivo sa ustavnopravnog stanovišta, potpuno pogrešnom, više političkom nego pravnom formom rješavanja jednog izuzetno važnog ustavnog spora, jer se zasniva na krajnje problematičnom pravnom stanovištu, pa se većinsko mišljenje može označiti kao pogrešno i ustavnosudski neprihvatljivo, sa sljedećih razloga:

$\mathrm{Na}$ osnovu izloženog proizilazi da obrada ličnih podataka koja podrazumijeva dobrovoljnu saglasnost lica datu u pismenoj formi, usmeno na zapisnik ili iskazanom konkludentnom radnjom, kojom lice nakon što je informisano o namjeri obrade, izražava pristanak da se njegovi podaci obrađuju za određenu namjenu i da data saglasnost može biti povučena u svakom trenutku, ne predstavlja povredu odredaba člana 43 st. 1 i 2 Ustava i čl. 8 Evropske konvencije za zaštitu ljudskih prava i osnovnih sloboda, jer zakonita obrada ličnih podataka podrazumijeva dobrovoljnu saglasnost lica datu u pismenoj ili usmenoj formi, pa samim tim odredbe člana 43 stav 6 Zakona o izboru odbornika i poslanika i člana 5 stav 1 Zakona o izboru Predsjednika Crne Gore nijesu nesaglasne s navedenim odredbama Ustava i Evropske konvencije."

Rezultat navedene odluke Ustavnog suda Crne Gore je preko hiljadu podnijetih krivičnih prijava zbog falsifikovanja potpisa, protiv kandidata za predsjednika Crne Gore, koje još nijesu procesuirane, pa je nekoliko NVO pokrenulo postupak za izmjene i dopune Zakona o izboru odbornika i poslanika.

\footnotetext{
${ }^{71}$ Izdvojena zajednička mišljenja sudija Miodraga Iličkovića i Milorada Gogića i 18 izdvojenih mišljenja sudije Hamdije Šarkinovića.

${ }_{72}$ Sudija Hamdija Šarkinović 9, sudija Budimir Šćepanović i sudija Milorad Gogić po jedno i zajedničko sudije Miodraga Iličkovića i Milorada Gogića.

73 Sudija Hamdija Šarkinović 9, sudija Budimir Šćepanović i sudija Gogić po jedno i zajedničko sudije Miodraga Iličkovića i Milorada Gogića 4.
} 
Mr. Hamdija Šarkinović: Izdvojeno mišljenje u praksi Ustavnog suda Crne Gore Zbornik radova Pravnog fakulteta u Splitu, god. 58, 3/2021, str. 683-709

2.2.1. Ustavni sud Crne Gore na sjednici od 24. februara 2017. godine donio je rješenje u predmetu U-II br. 56/14 o neprihvatanju inicijative za pokretanje postupka za ocjenu ustavnosti i zakonitosti odredbe člana 14 stav 1 Ugovora o uređenju odnosa od zajedničkog interesa između Vlade Crne Gore i Islamske zajednice u Crnoj Gori, broj 01-427, od 30. januara 2012. godine, koji su zaključili Vlada Crne Gore i Islamska zajednica u Crnoj Gori. ${ }^{74}$

2.2.2. Ustavni sud Crne Gore na sjednici od 27. juna 2017. godine donio je odluku u predmetu U-II br. 36/15, kojom je ukinuo Sporazum o realizaciji rekonstrukcije seoskog vodovoda "Završ, Đurička Rijeka", broj 031-613, od 20. septembra 2013. godine, koji su zaključili predsjednik Opštine Plav i predsjednik Režijskog odbora i koji prestaje da važi danom objavljivanja date odluke u "Službenom listu Crne Gore". ${ }^{75}$

U navedena dva predmeta Ustavni sud prethodno je trebao da odluči jesu li navedeni akti opšti ili posebni akti, od čega zavisi pravilno odlučivanje. Premo mojem mišljenju radi se o posebnim aktima te je Ustavni sud trebalo da, saglasno odredbama člana 49 st. 3, a u vezi čl. 37, Zakona o Ustavnom sudu rješenjem odbaci inicijative, bez meritornog idlučivanja kako je odlučio Sud, na osnovu sljedećih razloga:

U pravnom sistemu Crne Gore nema definicije što se podrazumijeva pod pojmom drugi propis i opšti akt kao mogućim predmetom ocjene njegove saglasnosti s Ustavom i zakonom. To i nije zadatak ni ustavotvorca niti zakonodavca, već onoga ko tumači pravne propise, bilo s ciljem da ih objasni bilo da ih primijeni na konkretnim društvenim odnosima. Analizom normativnog dijela ustavnog poretka uočava se da on ne sadrži pojmovno određenje, već sadrži slične pojmove koji se ponekad koriste kao sinonimi, a koji su nekad širi po obuhvatu i poklapaju se s pojmom drugi propis ili se odnose na propise koji su opštenormativni akti, a u ustavnopravnom smislu nijesu drugi propisi. Pod pojmom opšti akt u pravu se mogu podvesti svi pravni propisi koji kao pravni akti sadrže opšte odredbe i koji na opšti način regulišu društvene odnose. Ovaj se pojam može uzeti kao sveobuhvatni za sve pravne propise i šire od toga, jer je on širi od pojma opšti pravni akt. Pravna teorija dala je odgovor na ova pitanja prihvatajući koncepciju hijerarhije pravnih propisa, dajući im u okviru hijerarhije određeni rang, pošavši od pravne snage koju im je ustavotvorac i zakonodavac Ustavom Crne Gore odredio.

Ustavom je propisano da opština ima svojstvo pravnog lica i da donosi statut i opšte akte. ${ }^{76}$ Zakonom o objavljivanju propisa i drugih akata ${ }^{77}$ propisano je da se zakoni i drugi propisi koje donose nadležni organi Crne Gore, kao i drugi akti za koje je to određeno zakonom, propisom Vlade Crne Gore ili za koje ti organi odluče objavljuju u "Službenom listu Crne Gore". Nadalje, Zakonom je propisano da se akti privrednih društava, ustanova, nevladinih organizacija i drugih pravnih lica

74 Službeni list $C G$, br. 43/17.

75 Isto, 60/17.

76 Ustav Crne Gore, član 115, st. 1 i 2.

77 Zakon o objavljivanju propisa i drugih akata Crne Gore, član 2. 
objavljuju na način koji odrede ti subjekti, ako zakonom nije drugačije određeno, ${ }^{78}$ da je objavljivanje zakona, drugih propisa i akata u "Službenom listu Crne Gore" djelatnost od javnog interesa. ${ }^{79}$ Pored ostalih akata, u "Službenom listu" objavljuju se uredbe, odluke i drugi akti Vlade, ${ }^{80}$ akti regulatornih organa, drugih pravnih lica i subjekata (savjeta, komisija i sl.) doneseni u izvršavanju javnih ovlašćenja ${ }^{81}$ te propisi organa opštine, Prijestonice, Glavnog grada i gradske opštine, kao i drugi akti za koje je to određeno zakonom i njihovim statutima. ${ }^{82}$

Pojam opšteg pravnog akta akademik Radomir Lukić definiše kao akt koji sadrži pravnu normu koja se odnosi na neodređeni broj slučajeva, da je opšteobavezujuća i da su svi subjekti koji ispunjavaju uslove predviđene u opštoj pravnoj normi dužni da se ponašaju po njoj. Opšti akt je izvor prava, a "izvor prava u formalnom smislu jeste ono o čemu se nalaze opšteobavezujuće pravne norme, tj. norme koje važe za sve određene situacije istog tipa predviđene u toj normi". ${ }^{83}$

Pod pojmom drugi propis podrazumijevamo akt koji "nije ni zakon ni drugi propis", jer ne uređuje odnose na apstraktan način, ne primjenjuje se na širi krug adresata i nema opšteobavezni karakter, odnosno akt koji na opšti način uređuje pravne odnose za neodređeni broj adresata koji sadrži opšta pravila ponašanja. Za razlikovanje opštih i pojedinačnih akata osvnovni su ovi elementi: za opšti akt je karakteristično da u njemu sadržana norma predviđa odnose (životne situacije) do kojih će doći, dok pojedinačni akt konkretni odnos zatiče; opšti akt reguliše niz u osnovi ponovljenih odnosa, a pojedinačni odnos koji je neponovljiv i opšti akt unaprijed reguliše odnose (prije nego se dese), a pojedinačni akt ih reguliše po nastanku.

$\mathrm{Na}$ osnovu navedenog, ostali propisi definisali bi se kao određeni akti koji na opšti (apstraktan) način uređuju pravne odnose za neodređeni broj adresata, koji sadrže opšta pravila ponašanja u određenim područjima života i djelovanja i koji se obavezno objavljuju u "Službenom listu" kako bi proizveli pravne posljedice.

Ustavni sud Crne Gore izrazio je svoj stav o ovom pitanju u odluci U-I br. 30/15, od 24. jula 2014. godine:

"6. Odredbom 149. stav 1. tačka 2. Ustava ustanovljena je nadležnost Ustavnog suda da odlučuje o ustavnosti i zakonitosti opštih pravnih akata, odnosno drugih propisa. Da bi jedan akt imao karakter opšteg pravnog akta ili drugog propisa potrebno je da sadrži određene pravne elemente koji ga kao takvog određuju. Za pravilno određenje pravne prirode svakog pravnog akta neophodno je cijeniti ne samo njegovu formalnu strukturu, već i sadržinu koja, u suštini, opredjeljuje pravnu prirodu akta u slučaju kada se naziv akta po smislu ne slaže sa njegovom sadržinom. Opšti akt se donosi na osnovu zakonskog ovlašćenja i u granicama ovlašćenja

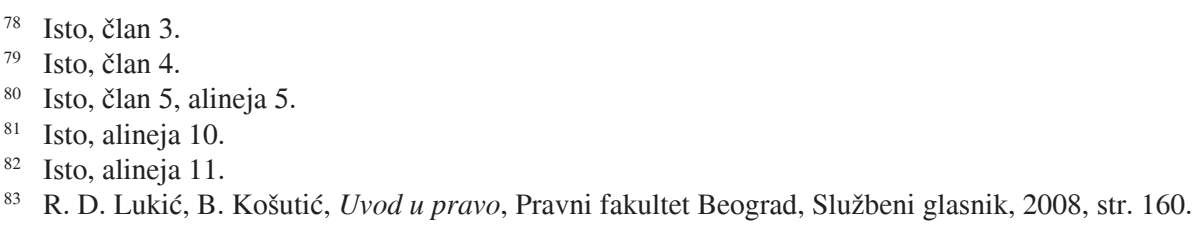


Mr. Hamdija Šarkinović: Izdvojeno mišljenje u praksi Ustavnog suda Crne Gore Zbornik radova Pravnog fakulteta u Splitu, god. 58, 3/2021, str. 683-709

sadržanih u zakonu i sadrži tačno određene djelove: naziv akta, naziv organa koji ga donosi, pravni osnov, odredbe kojima se na opšti način uređuju prava i obaveze za neodređeni broj lica i odredbe o načinu objavljivanja i stupanja na snagu. Opšti akt koji je donijet od strane nadležnog organa i po postupku predviđenom za njegovo donošenje, po ocjeni Ustavnog suda postaje opšteobavezan samo ako je na odgovarajući način objavljen i ako je stupio na snagu, jer je primjena opšteg pravnog akta Ustavom uslovljena njegovim zvaničnim objavljivanjem i stupanjem na snagu (po isteku vacatio legisa). Samo opšti pravni akt koji je stupio na snagu u skladu s Ustavom može se primjenjivati i proizvoditi pravno dejstvo erga omnes." 84

2.2.3. Ustavni sud Crne Gore je na sjednici od 29. maja 2017. godine donio odluku u predmetu U-I br. 28/15 i 39/16, kojom je ukinuo odredbe člana 234 stav 1 tačka 1 i člana 235 stav 1 tačke 1 i 2 te stav 3 Zakona o prekršajima ("Službeni list Crne Gore", br. 1/11, 6/11, 39/11 i 32/14), kojim je propisano: "Naplata novčane kazne može se izvršiti: pasivnim izvršenjem preko Registra novčanih kazni u skladu sa članom 235. ovog zakona" i: "(1) Osuđenom, odnosno kažnjenom za prekršaj iz oblasti bezbjednosti saobraćaja, dok ne plati sve novčane kazne i troškove postupka koji su evidentirani u Registru novčanih kazni, neće se dozvoliti: registracija ili produženje važenja registracije motornog vozila; izdavanje ili produženje važenja vozačke dozvole." Izdvojeno mišljenje urađeno je sa sljedećih razloga: ${ }^{85}$

1. Članovima 234 stav 1 tačka 1 i 235 stav 1 tačke 1 i 2 te stav 3 Zakona o prekršajima uveden je Registar pravosnažnih izrečenih a neuplaćenih novčanih kazni i obavezno uskraćivanje izdavanja određenih dozvola i dokumenata licima registrovanim zbog nenaplaćene novčane kazne. Registar je elektronska baza podataka o osuđenim licima kojima je pravosnažno izrečena novčana kazna a koji tu kaznu nijesu platili u određenom roku. Cilj propisivanja ovih odredbi jeste povećanje efikasnosti naplate novčanih kazni izrečenih počiniocima prekršaja. U tu svrhu propisano je obligatorno uskraćivanje izdavanja dokumenata i dozvola zbog neuplaćene novčane kazne. Osim toga, ostavljena je mogućnost da se posebnim zakonima propišu i uskrate drugi dokumenti i dozvole kao posljedica neuplaćene novčane kazne. Naime, za postupanje organa državne uprave po članu 235 stav 1 tačka 1 i 2 te stav 3 nije odlučujuće je li prekršaj počinjen vozilom za koje bi se uskratila registracija ili produženje valjanosti registracije vozila. Vlasnik vozila, bilo to fizičko ili pravno lice, nije ograničen u svom pravu svojine ili drugim pravima nad vozilom, ako je prekršaj počinio neko drugi, zapošljeni kod pravnog lica, lice koje ga je iznajmilo ili osoba kojoj je vozilo dato na korištenje.

"2.1. Polazeći od opšte svrhe prekršajnopravnih sankcija da građani poštuju pravni sistem, da se izrazi društveni prijekor učiniocu zbog izvršenog prekršaja i da se utiče na njega i sva ostala lica da ubuduće ne čine prekršaj (član 6 ZOP), u slučaju članova 234 stav 1 tačka 1 i 235 stav 1 tač. 1 i 2 te stav 3 Zakona o prekršajima riječ je o mjerama koje otklanjaju uslove koji omogućavaju ili podsticajno djeluju na izvršenje novog prekršaja. Drugim riječima, osporeni članovi

84 Arhiv Ustavnog suda Crne Gore.

85 Službeni list CG, br. 43/17. 
234 stav 1 tačka 1 i 235 stav 1 tač. 1 i 2 i stav 3 Zakona o prekršajima usmjereni su na ostvarivanje dva, međusobno povezana, legitimna cilja: preventivno djelovanje radi sprečavanja činjenja prekršaja i djelotvorno sankcionisanje počinioca prekršaja, osobito u situacijama kad su se blaže sankcije i/ili druge zaštitne mjere pokazale nedjelotvornim.

3. Pitanje efikasnosti naplate kazni nije ustavnopravno pitanje, već pitanje svrsishodnosti rješenja/modela propisanih osporenim zakonskim odredbama. Izbor metoda kojima se nastoji uticati na ubrzanje naplate prekršajnih kazni, skraćivanje vremena, kao i sigurnost naplate i rasterećenje prekršajnih sudova legitimno je pravo zakonodavca, utemeljeno na ovlašćenju iz člana 82 stav 2, a u vezi s članom 16 Ustava.

4. Mogućnost nekog alternativnog rješenja sama po sebi ne čini Zakon o prekršajima nesaglasnim s Ustavom, pod uslovom da je rješenje koje je ponudio zakonodavac ostalo unutar ustavnopravno prihvatljivih granica. Ustavni sud nije nadležan davati svoju ocjenu o tome je li ono najbolje za uređenje dotičnog pitanja, odnosno jesu li zakonodavna ovlašćenja u tom pitanju trebala biti iskorištene na drugačiji način.

5.1. Sljedstveno prethodnom, mjere osporene članovima 234 stav 1 tačka 1 i 235 stav 1 tač. 1 i 2 te stav 3 Zakona o prekršajima, kao svojevrsne zaštitne mjere, predstavljaju ograničenje svojinskih prava adresata osporene norme. Međutim, polazeći od legitimnog cilja zbog kojih su ta ograničenja propisana, ocjenjujem da su ona srazmjerna cilju koji se njihovim propisivanjem želio postići. Drugim riječima, za njihovo propisivanje postoji razumno i objektivno opravdanje.

5.2. Prema tome, članovi 234 stav 1 tačka 1 i 235 stav 1 tač. 1 i 2 te stav 3 Zakona o prekršajima saglasni su s načelima vladavine prava i pravne sigurnosti objektivnog pravnog poretka u području prekršajnog zakonodavstva, samim tim nijesu povrijeđene odredbe člana 24 i 58 Ustava Crne Gore i člana 1 Protokola broj 1 uz Evropsku konvenciju."

2.2.4. U predmetu U-I br.34/18, U-III br. 1970/18 i U-III br.1987/18, od 27. septembra 2019. godine, pokazao je neadekvatno regulisanje odnosno nepotpuno regulisanje instituta izdvojenog mišljenja Poslovnikom Ustavnog suda.

Navedenom odlukom ukinute su odredba člana 119 stav 2 Zakonika o krivičnom postupku ("Službeni list Crne Gore", br. 57/09 i 49/10), u dijelu koji glasi: "a ako i poslije toga odbije da svjedoči, može se zatvoriti. Zatvor traje dok svjedok pristane da svjedoči ili dok njegovo saslušanje postane nepotrebno ili dok se krivični postupak završi, ali najduže dva mjeseca" i prestaje da važi danom objavljivanja date odluke, kao i rješenja Apelacionog suda Crne Gore, Kvsž. br. 143/18, od 2. decembra 2018. godine i Kvs. br. 328/18, od 28. novembra 2018. godine (ustavna žalba U-III br. 1970/18) i rješenje Apelacionog suda Crne Gore, Kvsž. br. 144/18, od 2. decembra 2018. godine i rješenje Višeg suda u Podgorici, Kvs. br. 329/18, od 28. novembra 2018. godine (ustavna žalba U-III br.1987/18).

U veoma kratkom i bespredmetnom obrazloženju izdvojenog mišljenja nije ukazano na esencijalni dio: da nije postojao nijedan razlog za ukidanje navedenih 
odredbi Zakona, a da je ukidanjem rješenja Apelacionog suda Ustavni sud protivno zakonu naredio oslobađanje poslanika koji su bez odobrenja Parlamenta stavljeni u pritvor, jer odluke Ustavnog suda imaju kasatorno dejstvo, pa će ova odluka postati primjer kako ne treba donositi odluke, da bi se prikrilo nezakonito djelovanje redovnih sudova.

Ovaj predmet karakterističan je po tome što Poslovnik Ustavnog suda ne sadrži odredbe o institutu izdvojenog mišljenja, pa je na navedenu odluku sudija najavio izdvojeno mišljenje, ali ono nije objavljeno do 29. novembra 2020. godine, više od godinu dana, zbog čega nije moglo biti objavljeno u "Službenom listu Crne Gore". Odredbama člana 152 st. 2 Ustava Crne Gore propisano je da, kad Ustavni sud utvrdi da zakon nije u saglasnosti s Ustavom i potvrđenim i objavljenim međunarodnim ugovorima, odnosno da drugi propis nije saglasan s Ustavom i zakonom, taj zakon i drugi propis prestaje da važi danom objavljivanja odluke Ustavnog suda. ${ }^{86}$ Odluka je objavljena po isteku roka od godinu dana ${ }^{87}$ nakon što ju je sudija izjavio u pisanoj formi, usljed interesovanja sredstava javnog informisanja. ${ }^{88}$

3. U predmetima po ustavnim žalbama najčešće se izdvojena mišljenja odnose na predmete iz svojinskih odnosa i građevinskog prava zbog arbitrarnog odlučivanja usljed povrede člana 32 Ustava i član 6 Evropske konvencije za zaštitu ljudskih prava i osnovnih sloboda.

\section{ZAKLJUČAK}

Institut izdvojenog mišljenja u istoriji je imao korektivni i reformski uticaj na razvoj pravnog sistema. Mišljenje većine je po formi i suštini kolektivno, sastavljeno i uređeno gledište većine. Međutim, kada je u pitanju izdvojeno

86 Prijedlog sudije Šarkinovića za izmjenu i dopunu Poslovnika Ustavnog suda Crne Gore,SU. br.14/97 od 13,3.1997.godine. Član 1. 1) Sudija ima pravo na izdvojeno mišljenje ako većina sudija na sjednici Ustavnog suda prihvati odluku ili rješenje čijoj se izreci i/ili čijem se obrazloženju sudija protivi. 2) Sudija koji na sjednici Ustavnog suda izdvoji mišljenje u pogledu izreke i/ili obrazloženja odluke i rješenja i usmeno ga obrazloži na sjednici Ustavnog suda dužan je da ga pisano obrazloži. 3) Izdvojeno mišljenje može izraditi i više sudija zajedno ako se protive izreci i/ili obrazloženju odluke ili rješenja zbog istovjetnih pravnih razloga koji su usmeno obrazloženi na sjednici Ustavnog suda (zbirno izdvojeno mišljenje). Zbirno izdvojeno mišljenje potpisuju sve sudije koje su izdvojile svoja mišljenja. Clan 2. 1) Izdvojeno mišljenje sudija je dužan usmeno najaviti na sjednici Ustavnog suda nakon što predsjednik Ustavnog suda, poslije provedenog postupka glasanja, objavi da je odluka, odnosno rješenje, o čijoj se izreci i/ili obrazloženju sudija protivi. 2) U slučaju iz stava 1 ovog člana sudija koji je najavio izdvojeno mišljenje ima pravo istovremeno zahtijevati da se donesena odluka ili rješenje, zajedno s izdvojenim mišljenjem, objavi u Službenom listu Crne Gore. 3) Sudija je dužan pismeno obrazložiti i dostaviti predsjedniku Ustavnog suda izdvojeno mišljenje u roku petnaest dana od dana donošenja odluke, odnosno rješenja na sjednici Ustavnog suda. 4) Do dostave izdvojenog mišljenja ili do isteka roka iz stava 3 ovog člana, odluka, odnosno rješenje ne otprema se na objavu. Ako izdvojeno mišljenje nije dostavljeno predsjedniku Ustavnog suda do isteka roka iz stava 3 ovog člana, odluka odnosno rješenje otprema se radi objave u Službenom listu, a naknadno dostavljeno izdvojeno mišljenje uvezuje se u ustavnosudski spis i čini njegov sastavni dio. 5) Ovjereni prijepis odluke, odnosno rješenja, s izdvojenim mišljenjem otprema se učesnicima u postupku i prije isteka roka iz stava 3 ovog člana.

87 Obavještenje sudije Su. br. 777/20 od 24. 11. 2020.

88 Dnevni list Vijesti, od 7. novembra 2020. godine, tekst "Stavljanje u pritvor nije ukinuto". 
mišljenje, sudija je sasvim sam i može izraziti svoju ličnost, svoju filozofiju i svoja necenzurisana uvjerenja. Izdvojena mišljenja su moćno oružje protiv grešaka, ona često objašnjavaju mišljenje većine. "Sudije su ljudska bića i oblačenjem sudijske odore njihova ljudska osjećanja ne nestaju. Sala za konferencije nije molitveni sastanak na kome se očekuje da svi klimnu glavom 'Amin'; to je više bojno polje na kome se suprotstavljene filozofije sučeljavaju prsa u prsa. Svaki pojedinac iz opšte javnosti i svaki član advokatske komore treba da poželi 'borbenog sudiju' koji će dati sve od sebe da pravda bude zadovoljena. Gotovo svako pitanje ima dvije strane; advokat ne može uvijek biti na strani pobjednika, niti se bilo koji pojedinac opšte javnosti može osloniti na to da će uvijek biti na strani većine." 89 Jedna od važnih uloga izdvojenog mišljenja u razvoju američke jurisprudencije jeste njegov uticaj na zakonodavstvo. Na primjer, neslaganje sudije Iredell u predmetu Chisholm protiv Georgia (Džordžije) postalo je dio vrhovnog zakona zemlje u jedanaestom amandmanu ${ }^{90}$ saveznog Ustava.

Uloga izdvojenog mišljenja je da je to prognoza za stvari koje dolaze. Autori izdvojenog mišljenja obično su ljudi koji gledaju unaprijed - ne unazad, niti u neposrednu sadašnjost - već u budućnost. U članku koji je napisao sudija William O. Douglas, sudija saradnik Vrhovnog suda Sjedinjenih Država, piše: ${ }^{11}$

"Izvjesnost i jednoglasnost u zakonu mogući su kako u fašističkom tako i u komunističkom sistemu. Oni nijesu samo mogući; oni su neophodni; jer je potpuna potčinjenost političkom režimu nužni uslov za opstanak sudstva pod bilo kojim sistemom. Ne mogu se zamisliti Hitlerovi sudovi koji učestvuju u javnoj raspravi o principima Der Fuehrer, s manjinom od jednog do četvorice koji osuđuju ili prekoravaju same principe. Ne može se zamisliti sudija komunističkog suda koji bi se suprotstavio uredbama Kremlja.

Neslaganje među sudijama jednako je istinito za karakter demokratije kao i sama sloboda govora. Izdvojeno mišljenje podjednako je istinski američko kao i Otisovo denunciranje opštih naloga, kao što su to i podnesci za građanske slobode Thomasa Painea, Thomasa Jeffersona ili Jamesa Madisona...

Kad pređemo na ustavna pitanja, neizvjesnost se nužno povećava. Sudija od kojeg se traži da objasni ili tumači Ustav često odbija sjaj kojim su ga posuli njegovi prethodnici. Jer sjaj može, prema njegovom mišljenju, uvrijediti duh Ustava ili učiniti nasilje nad njim. To je bilo iskustvo ove generacije kao i svih prethodnih. To će isto biti iskustvo i onih koji dolaze. I tako bi trebalo i da bude. Jer, Ustav je taj, a ne neko njegovo tumačenje, koji smo se zakleli da ćemo braniti... Ustav je napisan za sva vremena i za sve vjekove. Izgubio bi svoj veliki karakter i postao

89 J. W. Carter, Dissenting Opinions), 4 Hastings L.J. 118 (1953). Dostupno na: https:// repository.uchastings.edu/hastings_law_journal/vol4/iss $2 / 5$

90 Sudska moć Sjedinjenih Država se ne tumači tako da se proširuje na bilo koju pravnu tužbu ili parnični postupak koje su protiv neke od Sjedinjenih Država pokrenuli ili procesuirali državljani neke druge države ili državljani ili subjekti bilo koje strane države.

91 J. Am. Jud. Soci., 104, 107. 
slab kad bi mu se dozvolilo da bude obavijen uskim, legalističkim pojmovima koji su dominirali razmišljanjem jedne generacije." 92

Izdvojena mišljenja se u pravnom sistemu Crne Gore mogu izjaviti na sve odluke Ustavnog suda u kojima je nadležan Ustavni sud, shodno članu 149 st. 1 Ustava Crne Gore, a nijesu dozvoljena na odluke i rješenja Ustavnog suda kojima se obustavlja izvršenje pojedinačnog akta, odnosno radnje, ukida mjera obustave ili odbacuje zahtjev za obustavu izvršenja pojedinačnog akta ili radnje.

Izdvojeno mišljenje je autorski tekst sudije koji treba da služi za kasniju sudsku praksu, a ne promociji sudije, jer prikladna i dobro utemeljena mišljenja mogu pomoći boljem prihvatanju sudskih odluka od stranaka, politike i javnosti, dok pretjerana i polemička izdvojena mišljenja mogu naškoditi prihvatanju odluka, a ultimativno i ugledu suda.

Institucija izdvojenog mišljenja nije zaživjela u praksi Ustavnog suda Crne Gore. Propisi koji regulišu izdvojeno mišljenje su neadekvatni te je potrebno izvršiti izmjene i dopune Poslovnika Ustavnog suda Crne Gore, kako se ne bi dešavalo da se blokira rad Ustavnog suda od sudije koji izjavi da će podnijeti izdvojeno mišljenje i poslije odustane. Uzdržanost sudija za podnošenje izdvojenih mišljenja dokazuje da se pojedine sudije nijesu oslobodile komunističkog nasljeđa, a i pojedina izdvojena mišljenja ne sadrže ozbiljnu analizu kojom bi se na zadovoljajući način upoznala laička i stručna javnost, pa je potrebno njihov kvalitet podići na viši nivo. Neophodno je propisati obavezu da se izdvojeno mišljenje objavi u "Službenom listu Crne Gore", ukoliko zahtijeva sudija izvjestilac, kao i na websiteu Ustavnog suda, jer se sam sudija stavlja na provjeru kod pravničke i političke javnosti.

\section{LITERATURA}

1. Alder, J., "Dissents in Courts of Last Resort: Tragic Choices?", Oxford Journal of Legal Studies, v. 20, no. 2, 2000.

2. Amram, P. W., The Dissenting Opinion Comes to the German Courts, 6 AM. J. COMP. L. 108, 110, 1957.

3. Ancel, J.-P., Les opinions dissidentes, dostupno na http://www.courdecassation.fr/ IMG/File/opinions_dissidentes_jp_ancel.pdf

4. Antić, T., "Izdvojeno mišljenje u sudskim postupcima i praksa Ustavnog suda Republike Hrvatske", Zbornik Pravnog fakulteta Sveučilišta u Rijeci, br. 2/2016.

5. Bierlein, B., "The constitutional legal protection of fundamental rights: possibilities and scope of access of an individual", rad predstavljen na Svjetskoj konferenciji o ustavnoj pravdi 2011. godine, dostupan na http://www.venice.coe.int/VCCJ/Rio/ Papers/AUT_Bierlein_E.pdf.

6. Black's Law Dictionary, St. Paul, Minn.: West Publishing Co, 1979.

7. Bundesverfassungsgericht, Case No. 1 BvR 586/62, 610/63, 512/64, DEJURE 20, 162 (Aug. 5, 1966), dostupno na http://dejure.org/dienste/vernetzung/

92 J. W. Carter, Dissenting Opinions (Izdvojena mišljenja), 4 Hastings L.J. 120 (1953). 
rechtsprechung?Text=BVerfGE $\% 2020 \% 2 \mathrm{C} \% 20162 \&$ Suche $=\mathrm{B}$ VerfGE $\% 2020$ $\% 2 \mathrm{C} \% 20162$.

8. Cameron, I. M., "Majority Rule; the Development of General Principle in Cases on Chartered Corporations", Melbourne University Law Review, 6, v. 15, no. 1, 1985.

9. Carter, J. W., Dissenting Opinions (Izdvojena mišljenja), 4 Hastings L.J. 120, 1953.

10. Carter, J. W., Dissenting Opinions, 4 Hastings L.J. 118, 1953.

11. Chapter XIV of the Ordenanzas de Medina, in Novíssima Recompilación de las Leyes de España, Tomo II, Boletín Oficial del Estado 350, 1976.

12. Crnić, J., Komentar ustavnog zakona o Ustavnom sudu Republike Hrvatske, Zagreb: Narodne novine, 2002.

13. De Tocqueville, A., O demokraciji u Americi, Zagreb: Informator, 1995.

14. Denti, V., "Per il ritorno al "voto di scissura" nelle decisioni giudiziarie", in Le opinioni dissenzienti dei giudici costituzionali ed internazionali 1, 3-6 (Costantino Mortati ed.), 1964.

15. Dnevni list Vijesti, od 7. novembra 2020. godine, tekst "Stavljanje u pritvor nije ukinuto".

16. Đorđević, J., Ustavno pravo, Beograd: Savremena administracija, 1976.

17. European Parliament, Dessenting Opinium in the Supreme Courts of the Member States, 2012.

18. Federal Constitutional Law No. 1-FKZ on the Constitutional Court (21/7/1994, amendments 8/2/2001).

19. Freixes, T., "La pratique des opinions dissidentes en Espagne", u Nouveaux Cahiers du Conseil Constitutionnel, 2000, dostupno na http://www.conseil-constitutionnel.fr/ conseilconstitutionnel/francais/nouveauk-cahiers-du-conseil/cahier- n-8 / la-pratikuedes-vievs-disidentes-enespagne.52543.html

20. Generalni direktorat za spoljne politike Evropskog parlamenta, Izdvojena mišljenja na vrhovnim sudovima država članica, 2012.

21. Guerrero Pico, C., "L'opinione dissenziente nella prassi del Tribunal Constitucional spagnolo (1994-2009)", dostupno na www.cortecostituzionale.it/documenti/ convegni_seminari/CC_SS_opinione_dissenziente_12012010.pdf

22. Hale, B. Presuda Vrhovnog suda, 2010, dostupno na http://www.supremecourt.gov. uk/docs/speech_100930.pdf.

23. Hanretty, C., "Dissenting opinions in the UKSC", dostupna na http://ukscblog.com/ dissenting-opinons-in-the-uksc.

24. http://www.supremecourt.gov.cy/judicial/sc.nsf/DMLSCourt_en/DMLSCourt_ en?OpenDocument

25. https://repository.uchastings.edu/hastings_law_journal/vol4/iss $2 / 5$

26. Ingman, T., The English Legal Process, Oxford: OUP, 2011.

27. Journal für Rechtspolitik, n. 7/1999.

28. Kelman, K., "Dissenting Opinions in Constitutional Court, German Law Journal, $14,135 / 1371$. 
29. Krbek, I., Ustavno sudovanje, Zagreb: Jugoslavenska akademija znanosti i umjetnosti, 1960.

30. Laffranque, J., "Dissenting Opinion and Judicial Independence", Juridical International Law Review, University of Tartu, VIII/2003.

31. Laffranque, J., "Izdvojeno mišljenje na Evropskom sudu pravde - Mogući doprinos Estonije demokratizaciji pravosudnog sistema Evropske unije", Juridica International, IKS 2003.

32. Lester, Lord A., "The Impact of the Human Rights Act on Public Law", u J. Beatson, C. Forsyth and I. Hare (eds.), Constitutional Reform in the United Kingdom: Practice and Principles, Oxford: Hart Publishing, 1998.

33. Ley Organica 2/1979 del Tribunal Constitucional.

34. Ley Organica 6/1985 del Poder Judicial

35. Ley Organica 6/2007.

36. Luatti, L., Profili costituzionali del voto particolare. L'esperienza del Tribunale Costituzionale Spagnolo 163-69 (Giuffrè ed.), 1995.

37. Lukić, R. D., Košutić, B., Uvod u pravo, Beograd: Pravni fakultet, Službeni glasnik, 2008.

38. Luther, J., "L'esperienza del voto dissenziente nei paesi di lingua tedesca", in Politica del diritto 241, 244, 1994.

39. Lynch, A., "Is Judicial Dissent Constitutionally Protected", Macquarie Law Journal, v. 4, 2004.

40. Malsch, M., Democracy In the Courts : Lay Participation In European Criminal Justice Systems. Farnham: Ashgate, 2009.

41. Marković, R., Ustavno pravo i političke institucije, Beograd: Službeni glasnik, 1995.

42. McGinley, G. P. J., "The Search for Unity: The Impact of Consensus Seeking Procedures in Appellate Courts", Adelaide Law Review, vol. 11/1987, 203-214.

43. Milgramm, K. H., Separete Opinium und Sondervotum in der Rechprechung des Supreme Court of the Unites States und des Bundesverfassungsgerichts, Berlin: Duncker \& Humbolt, 1985.

44. Nadelmann, K. H., Non-Disclosure of Dissents in Constitutional Courts: Italy and West Germany, 13 AM. J. COMP. L. 268, 272, 1964.

45. Nadelmann, K., "The Judical Dissent", American Journal of Comparative Law, vol. 8, 1959.

46. Nelissen, B., "Judicial Loyalty Through Dissent or Why The Timing is Perfect for Belgium to Embrace Separate Opinions", Electronic Journal of Comparative Law, vol. 15.1, 2011.

47. Nicolatos, M. M., Parparinos, L., Hadjiprodromou, M., Administrative justice in Europe: The Supreme Court of Cyprus, 2018, dostupno na http://www.aca-europe. eu/en/eurtour/i/countries/cyprus/cyprus_en.pdf.

48. Oneto, L. P., Le opinioni dissenzienti dei giudici della Corte costituzionale Tedesca, in Annali della facoltà di scienze politiche di Genova 1083, 1087 (1976-77).

49. Petrov, V., Simović, D., Ustavno pravo, Beograd: Službeni glasnik, 2018. 
50. Poslovnik o radu, Litvanija, dostupan na http://www.satv.tiesa.gov. lv/?lang $=2 \& \operatorname{mid}=10$.

51. Rigaux, M.-F., La Cour constitutionnelle et les opinions séparées, 17. februara 2012, dostupno na http://www.justice-en-ligne.be/article404.html.

52. Smerdel, B., "O sudskoj slozi i izdvojenim mišljenjima", Informator, br. 5944, 2011.

53. Smerdel, B., Ustavno uređenje europske Hrvatske, II izmijenjeno i dopunjeno izdanje, Zagreb: Narodne novine, 2012.

54. Šarkinović, H., "Pola vijeka ustavnog sudstva u Crnoj Gori", u Pravni život, Beograd, $12 / 2013$.

55. Šuković, M., Ustavno pravo, Podgorica: CID, 2009.

56. United Bank Mizrahi protiv Migdal Cooperative Village [1995] IsrSC 49 (4) 221, dostupno na http://versa.cardozo.yu.edu/opinions/united-mizrahi-bank-v-migdalCooperative-Village

57. Van der Schiff, G., "Constitutional review by the judiciary in the Netherlands: A bridge too far?" German American Law Journal, vol. 11.2, 2010.

58. Van Dijk, P., "Constitutional review in the Netherlands", u Liber Amicorum Antonio La Pergola, Istituto Poligrafico e Zecca dello Stato, 2009.

59. Venice Commission, Council of Europe, Report on separate opinions of Constitutional Court, Strasburg, 2018, Opinion No. 932/2018.

60. Vitale, D., "The Value of Dissent in Constitutional Adjudication: a context-specific analysis", Review of Constitutional Studies, v. 19, no. 1, 2014.

61. Zakon o Ustavnom sudu Litvanije, usvojen 9. juna 1996. godine, dostupan na http:// www.satv.tiesa.gov.lv/?lang $=2 \& \mathrm{mid}=9$

\section{Izvori}

1. Obavještenje sudije Su. br. 777/20 od 24. 11. 2020.

2. Prijedlog sudije Šarkinovića za izmjenu i dopunu Poslovnika Ustavnog suda Crne Gore, SU. br. 14/97 od 13, 3.1997. godine.

3. Službeni list $C G, 60 / 17$.

4. Službeni list $C G$, br. $11 / 2015$.

5. Službeni list CG, br. 38/2013.

6. Službeni list $C G$, br. $43 / 17$.

7. Službeni list $C G$, br. $43 / 17$.

8. Službeni list Crne Gore, br. 1/2007.

9. Službeni list Crne Gore, br. 64/08.

10. Službeni list $S R C G$, br. 43/63.

11. Službeni list SRCG, br. 44/63.

12. Ustav Crne Gore, 2007.

13. Zakon o objavljivanju propisa i drugih akata Crne Gore. 


\section{SEPARATE OPINION IN THE PRACTICE OF THE CONSTITUTIONAL COURT OF MONTENEGRO}

A dissenting opinion is a recipe necessary for any court to be healthy and it plays a protective role when it comes to unfair legislation. There are two types of dissenting opinions - when a judge accepts the majority's decision on merits, but disagrees with reasons it is based on, and when a judge opposes both the decision on merits and the reasoning. A dissenting opinion emerged in the common law states, as well as in Spain in the $15^{\text {th }}$ century and in the Italian states in the $18^{\text {th }}$ century, to be taken over by the states of continental (civil) law in the middle of the last century. This institute has been challenged, re-examined, abandoned and reaccepted as an integral part of decision-making throughout history. In science, a dissenting opinion is defined as the opinion of one or more judges who disagree with the decision made by the majority. As far as Europe is concerned, this institute is not envisaged in Austria, Belgium, France, Malta and Luxembourg. The institute of dissenting opinion was regulated for the first time in the 1963 Constitution of the Federal Republic of Montenegro, and then in other constitutions, as well as in the Law on the Constitutional Court of Montenegro. A dissenting opinion may be expressed on all acts prescribed by Article 149, paragraph 1 of the Constitution of Montenegro, while it may not be expressed on decisions of the Constitutional Court suspending the execution of an individual act or action. A dissenting opinion has not taken root in the practice of the Constitutional Court of Montenegro, and the regulations governing the dissenting opinion are inadequate and need to be changed.

Key words: constitutional judiciary, Constitutional Court of Montenegro, separate opinion, significance 